\title{
Evaluation of secondary dentin formation for forensic age assessment by means of semi-automatic segmented ultrahigh field 9.4 T UTE MRI datasets
}

\author{
Maximilian Timme $^{1}$ (D) Jens Borkert ${ }^{1} \cdot$ Nina Nagelmann ${ }^{2} \cdot$ Andreas Schmeling $^{1}$ \\ Received: 10 August 2020 / Accepted: 10 September 2020 / Published online: 17 September 2020 \\ (C) The Author(s) 2020
}

\begin{abstract}
Dental methods are an important element of forensic age assessment of living persons. After the development of all the teeth, including third molars, is completed, degenerative characteristics can be used to assess age. The radiologically detectable reduction of the dental pulp cavity has been described as such a feature. We investigated the suitability of ultrahigh field 9.4 T ultrashort time echo (UTE) magnetic resonance imaging (MRI) for the evaluation of pulp cavity volume in relation to the total tooth volume in 4 extracted human teeth. The volume calculations were performed after semi-automatic segmentation by software AMIRA using the different intensities of the structures in the MRI dataset. The automatically selected intensity range was adjusted manually to the structures. The visual distinction of pulp and tooth structure was possible in all cases with in-plane resolution $<70 \mu \mathrm{m}$. Ratios of tooth/pulp volume were calculated, which could be suitable for age estimation procedures. Intensity shifts within the pulp were not always correctly assigned by the software in the course of segmentation. 9.4 T UTE-MRI technology is a forward-looking, radiation-free procedure that allows the volume of the dental pulp to be determined at high spatial resolution and is thus potentially a valuable instrument for the age assessment of living persons.
\end{abstract}

Keywords Age assessment $\cdot$ Secondary dentin formation $\cdot$ MRI $\cdot$ Dental age $\cdot$ Ultrashort time echo

\section{Introduction}

Forensic age assessment can provide clarity in the case of missing or doubtful age information and thus contribute to the execution of constitutional proceedings. In forensic age estimation, the grade of development of various skeletal and dental features is determined and compared with reference values [1]. Once tooth development is complete, only degenerative dental characteristics can be used for age assessment [2-6]. One such feature has long been known to be the reduction of the dental pulp due to secondary dentine formation [3, $7-10]$.

Maximilian Timme

maximilian.timme@ukmuenster.de

1 Institute of Legal Medicine, University Hospital Münster, Röntgenstraße 23, 48149 Münster, Germany

2 Department of Clinical Radiology, Translational Research Imaging Center (TRIC), University Hospital Münster,

Albert-Schweitzer-Campus 1, 48149 Münster, Germany
The physiological background of secondary dentin formation is that odontoblasts continue to produce dentin continuously after the completion of tooth development [11-13]. This so-called secondary dentine is added to the dentine facing the pulp, which reduces the volume of the pulp cavity during life. Today it is considered that secondary dentin formation is a cellular synthesis process independent of external factors [14]. The tertiary dentine must be distinguished from the secondary dentine. Tertiary dentin is a reaction of the odontoblasts to various pathological processes usually in the context of caries or wear $[15,16]$. Tertiary dentine formation does not correlate with age $[17,18]$. The differentiation between tertiary and secondary dentine has so far only been possible histologically, which is why great importance must be attached to not determining the formation of secondary dentine on pathologically influenced teeth for the propose of forensic age assessment [19]. In contrast, the feature seems to be independent, e.g., of orthodontic treatment [20].

In the recent past, increasing numbers of publications have reported an approach to calculate the actual volume of the dental pulp or a quotient of the volume of the hard tooth substance and the pulp [21-26]. These methods are based on 
the cone-beam $\mathrm{CT}(\mathrm{CBCT})$ for imaging. $\mathrm{CBCT}$ creates a 3D dataset from which the reconstruction of the structures is possible [9]. However, the CBCT is associated with a higher radiation exposure than the conventional dental radiological methods [27]. This fact is critical for this method.

A new development is the use of magnetic resonance imaging (MRI) technology in dental imaging, as a radiation-free method [28-30]. Consequently, the technology has already been used for dental age assessment [31-33]. However, imaging of hard tissues like the bone or teeth is still challenging because of their limited water content and solid structure [34]. Due to this special challenge, sequences that are sensitive despite ultrashort $\mathrm{T} 2$ relaxation can be used to analyze these tissues at relatively high spatial resolution and with a high signal to noise ratio [35]. One MRI sequence that meets these requirements is ultrashort time echo [36-39].

The aim of the present study was to examine whether UTEMRI is suitable for visualizing tooth hard tissue and dental pulp enabling calculation of a quotient for age assessment applicable on the different types of human teeth.

\section{Materials and methods}

This study was approved by the responsible ethics committee (2017-215-f-S). All donors of teeth signed a consent form for the use of their teeth for scientific purpose.

For the present study, a total of 4 extracted human teeth were examined by MRI. The teeth came from 2 males and 1 female aged 48, 54, and 78 years, respectively. All the teeth were extracted for medical indication. Only the teeth which did not show any visible pathological lesions were used for the examinations. The teeth were placed in $70 \%$ ethanol immediately after extraction. The teeth were an anterior tooth (FDI 11), a canine tooth (FDI 23), one premolar (FDI 14), and one molar (FDI 26).

Approximately $24 \mathrm{~h}$ before the MRI examinations, the teeth were taken from the alcohol, rinsed, and embedded in $1 \%$ agarose in a $5-\mathrm{ml}$ falcon tube and stored at $4{ }^{\circ} \mathrm{C}$ overnight.

MRI was performed on a 9.4 T Bruker Biospec 94/20 (Bruker BioSpin GmbH, Ettlingen, Germany) equipped with a 35-mm quadrature birdcage coil (Rapid Biomedical, Rimpar, Germany). The falcon tube with the embedded tooth was put directly into the $35-\mathrm{mm}$ micro-coil and fixed with paper towels in the middle of the coil to avoid movement artifacts and to position the sample in the isocenter. 3D UTE sequence was used with the following parameters: time to repetition, $8.0 \mathrm{~ms}$; time to echo, $0.020 \mathrm{~ms}$; flip angle, $5^{\circ}$; averages, 4; scan time, $1 \mathrm{~h} 12 \mathrm{~min}$; number of projections, 134,526; polar undersampling, 1.52; and Matrix, 256. Due to different types of examined teeth, field of view and spatial resolution had to be adjusted for each tooth. Table 1 shows the field of view and spatial resolution values for each tooth.
Table 1 Measurement data by tooth

\begin{tabular}{lll}
\hline Tooth $(\mathrm{FDI})$ & Field of view $\left(\mathrm{mm}^{3}\right)$ & Spatial resolution $\left(\mu \mathrm{m}^{3}\right)$ \\
\hline 11 & $17 \times 30 \times 17$ & $66 \times 117 \times 66$ \\
23 & $17 \times 35 \times 17$ & $66 \times 137 \times 66$ \\
14 & $17 \times 30 \times 17$ & $66 \times 117 \times 66$ \\
26 & $17 \times 31 \times 17$ & $66 \times 121 \times 66$ \\
\hline
\end{tabular}

3D reconstruction of MRI datasets was performed with AMIRA software (Visage Imaging GmbH, Berlin, Germany).

The semi-automatic segmentation was performed with the so-called "magic wand tool" of AMIRA software. The "magic wand tool" bases the selection off voxel color gradient. Thus, transferred to the MRI, the selection is based on the different intensities of the tissues. The automatically selected intensity range was adjusted manually to the structures. The range was adjusted until the area of the selection visually matched the area of the structure exactly. However, this adjustment of the assignment was only carried out in one slice. For segmentation, the selection made by the tool was not further corrected manually.

MRI data were further analyzed using profile plot analysis tool of ImageJ software (Version 1.50b, Wayne Rasband, National Institute of Health, USA). Signal intensities were reported as arbitrary units (au); values were given as mean.

\section{Results}

UTE-MRI enabled the embedding material, tooth structure, and pulp to be distinguished precisely. The pulp could be traced through the root canals to the apical foramen. A spatial in-plane resolution of $66 \mu \mathrm{m}$ was achieved for all the teeth. Table 1 shows the specific data measured for each tooth.

The embedding material showed a signal intensity of mean 16,051 au. In comparison, the hard tooth substance can be clearly distinguished with a signal intensity of mean 5639 au. The pulp showed a signal intensity of mean 13,452 au and is thus in a comparable range with the embedding material (Fig. 1)

In tooth 26 , significant intensity changes were observed within the area of the pulp (Fig. 1).

For all teeth, a 3D reconstruction could be generated, and the volumes could be calculated. Figure 2 shows the special formations the dental pulp can take. In tooth 26 , it becomes evident that the pulp, especially the root pulp, can take on special formations. Root canals that physiologically diverge and re-confluence within the root can be found. Table 2 lists the calculated volumes for each tooth. The calculated total volumes were between 605.80 and $992.92 \mathrm{~mm}^{3}$ for 11 and 26 , respectively. 
Different grey values in transverse section. Examples.
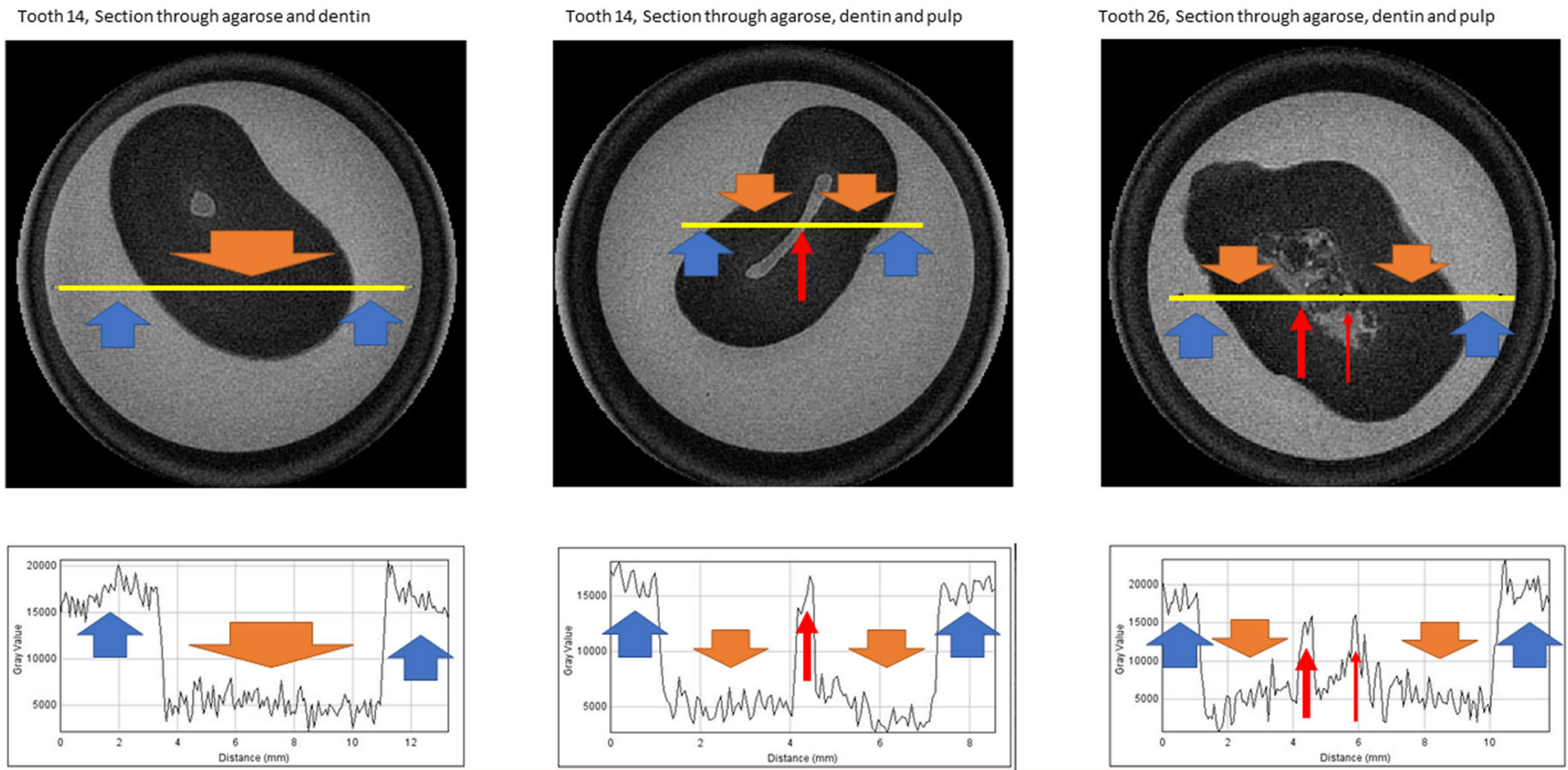

Section for plot, \#Agarose, \#Dentin, \# Pulp

GreyValue in plot in arbitrary units [au]

Fig. 1 Different grey values in transverse section. Examples

The values for the pulp volumes ranged from 12.70 (tooth 23) to $29.29 \mathrm{~mm}^{3}$ (tooth 26 ).

Ratios of tooth/pulp volume were calculated and given in Table 2.

\section{Discussion}

The purpose of this study was to examine whether modern MRI technology is suitable for imaging the dental pulp in such quality that a use in dental age assessment is possible. This approach is desirable, since on the one hand the possibilities of three-dimensional methods should be used in age assessment of living individuals, but on the other hand the radiation exposure should be kept as low as possible for reasons of radiation protection.

Using a tomograph with a field strength of $9.4 \mathrm{~T}$ and the UTE sequence, technology was applicated which is in the

Table 2 Volume calculations and quotients per tooth

\begin{tabular}{lllll}
\hline Tooth [FDI] & 11 & 14 & 23 & 26 \\
\hline Volume total $\left(\mathrm{mm}^{3}\right)$ & 605.80 & 762.37 & 723.11 & 992.92 \\
Volume pulp $\left(\mathrm{mm}^{3}\right)$ & 12.74 & 15.79 & 12.70 & 29.29 \\
$\begin{array}{l}\text { Quotient pulp/total } \\
(\%)\end{array}$ & 2.1 & 2.07 & 1.76 & 2.95 \\
\hline
\end{tabular}

range of what is currently technically possible. In this context, it should be noted that the field strengths of the tomographs, as they are used in the clinical context today, are in the range of 1.5 to $3 \mathrm{~T}$ or in exceptions up to $7 \mathrm{~T}[40,41]$. In addition, UTE technology is not yet widely available. Thus, the present study is a view in the direction of what could be possible in the field of forensic dental imaging in the future.

When measuring the secondary dentine formation for the purpose of age determination, one question is that of the most suitable teeth [22]. In the present study, it could be shown that for all human tooth types (front, canine, premolar, molar), the detailed imaging of the pulp up to the apical foramen is possible at high resolution. Therefore, this method does not necessarily have to be limited to single-rooted teeth. The challenge in the future will rather be the detection of pathological influences on secondary dentine formation. These teeth should be excluded from the age estimation in principle.

The spatial resolution is described as one of the most important parameters that objectively determine the image quality, especially in dental imaging, where fine details often need to be displayed [42]. With the selected parameters, an in-plane resolution of $66 \mu^{3}$ could be achieved in the present study. Thus, comparable values to those obtained in CBCT investigations could be achieved [43]. However, it should be noted that very high resolutions in $\mathrm{CBCT}$ are also associated with higher radiation exposure.

Further technical innovations in the field of segmentation will be necessary in the future, as a comparable study with 


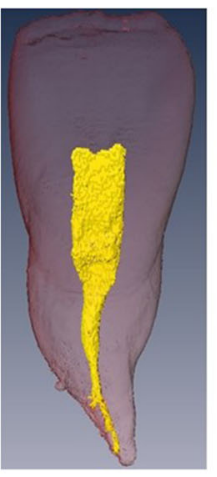

Tooth 11

Palatinal view

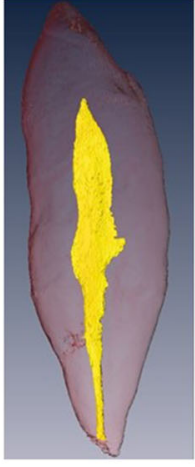

Tooth 23

Approximal view

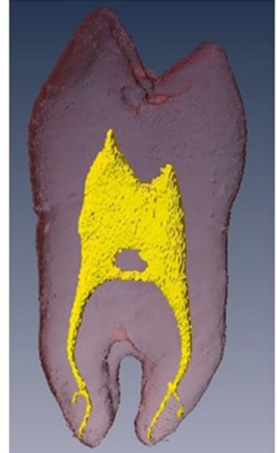

Tooth 14

Approximal view

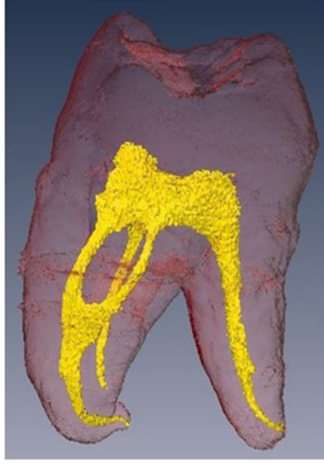

Tooth 26

Approximal view

Yellow: pulp

The 3D images show that the dental pulp can take on special shapes. The root canals can diverge and converge again before reaching the apical foramen. In addition, small side canals can be branched off from the main canals.

It becomes visible that these shapes cannot be captured in a 2D representation.

Fig. 2 3D reconstructions of all teeth

CBCT has shown that the segmentation procedure can influence the results [44]. However, it is not clear in this context how the segmentation methods can be combined with MRI technology.

Due to the research question, it was decided not to relate the pulp volume to the age of the tooth donor. This correlation has been examined in principle and, with reference to new MRI parameters, should be verified in large reference studies.

In addition, special statistical methods were not used because of the small number of cases. In view of the research question of the study, no additional knowledge gain was expected from the use of special statistical methods.

\section{Outlook and conclusions}

The promising results of the present study should be verified on a larger number of cases in the future. For this purpose, the age of the persons must also be correlated with the results of the volume measurements. This can also be used to determine which tooth correlates best with age. For the method of semiautomatic segmentation presented in this paper, the intra- and interrater agreement should be determined.

In addition, the accuracy of semi-automatic segmentation should be compared with manually corrected or fully automatic segmentation.

Furthermore, the method should also be tested against the current gold standard of CBCT in the future.

As soon as technically possible, the results of this in vitro approach should be transferred to in vivo.

All in all, 9.4 T UTE-MRI is a suitable, radiation-free tool for imaging tooth and pulp with a high spatial resolution for dental age assessment quite comparable with CBCT data. Further technical developments as well as scientific studies are necessary until practical application.

Acknowledgements Open Access funding enabled and organized by Projekt DEAL.

\section{Compliance with ethical standards}

Ethical approval for the study was obtained from the Ethics Committee of the Medical Association of Westfalen-Lippe and of the University of Muenster, Münster, Germany (2017-215-f-S). All donors of teeth signed a consent form for the use of their teeth for scientific purpose.

Conflict of interest The authors declare that they have no conflict of interest.

Open Access This article is licensed under a Creative Commons Attribution 4.0 International License, which permits use, sharing, adaptation, distribution and reproduction in any medium or format, as long as you give appropriate credit to the original author(s) and the source, provide a link to the Creative Commons licence, and indicate if changes were made. The images or other third party material in this article are included in the article's Creative Commons licence, unless indicated otherwise in a credit line to the material. If material is not included in the article's Creative Commons licence and your intended use is not permitted by statutory regulation or exceeds the permitted use, you will need to obtain permission directly from the copyright holder. To view a copy of this licence, visit http://creativecommons.org/licenses/by/4.0/.

\section{References}

1. Schmeling A, Dettmeyer R, Rudolf E, Vieth V, Geserick G (2016) Forensic age estimation. Dtsch Arzteblatt Int 113:44-50. https:// doi.org/10.3238/arztebl.2016.0044 
2. Marroquin TY, Karkhanis S, Kvaal SI, Vasudavan S, Kruger E, Tennant M (2017) Age estimation in adults by dental imaging assessment systematic review. Forensic Sci Int 275:203-211. https:// doi.org/10.1016/j.forsciint.2017.03.007

3. Gustafson G (1939) (1950) Age determination on teeth. J Am Dent Assoc 41:45-54

4. Timme M, Timme WH, Olze A, Ottow C, Ribbecke S, Pfeiffer H, Dettmeyer R, Schmeling A (2017) Dental age estimation in the living after completion of third molar mineralization: new data for Gustafson's criteria. Int J Legal Med 131:569-577. https://doi.org/ 10.1007/s00414-016-1492-3

5. Olze A, Hertel J, Schulz R, Wierer T, Schmeling A (2012) Radiographic evaluation of Gustafson's criteria for the purpose of forensic age diagnostics. Int J Legal Med 126:615-621. https://doi. org/10.1007/s00414-012-0701-y

6. Si X-Q, Chu G, Olze A, Schmidt S, Schulz R, Chen T, Pfeiffer H, Guo Y-C, Schmeling A (2019) Age assessment in the living using modified Gustafson's criteria in a northern Chinese population. Int $\mathbf{J}$ Legal Med 133:921-930. https://doi.org/10.1007/s00414-01902024-1

7. Solheim T (1992) Amount of secondary dentin as an indicator of age. Scand J Dent Res 100:193-199

8. Marroquin Penaloza TY, Karkhanis S, Kvaal SI, Nurul F, Kanagasingam S, Franklin D, Vasudavan S, Kruger E, Tennant M (2016) Application of the Kvaal method for adult dental age estimation using cone beam computed tomography (CBCT). J Forensic Leg Med 44:178-182. https://doi.org/10.1016/j.jflm. 2016.10.013

9. Pinchi V, Pradella F, Buti J, Baldinotti C, Focardi M, Norelli G-A (2015) A new age estimation procedure based on the 3D CBCT study of the pulp cavity and hard tissues of the teeth for forensic purposes: a pilot study. J Forensic Leg Med 36:150-157. https:// doi.org/10.1016/j.jflm.2015.09.015

10. Kvaal SI, Kolltveit KM, Thomsen IO, Solheim T (1995) Age estimation of adults from dental radiographs. Forensic Sci Int 74:175185

11. Lamster IB, Asadourian L, Del Carmen T (2000) Friedman PK (2016) The aging mouth: differentiating normal aging from disease. Periodontol 72:96-107. https://doi.org/10.1111/prd.12131

12. Burns KR, Maples WR (1976) Estimation of age from individual adult teeth. J Forensic Sci 21:343-356

13. Ghom A, Ghom SA (2014) Textbook of oral medicine, 3rd edn. Jaypee Brothers Medical Publishers (P) LTD, New Delhi

14. Murray PE, Stanley HR, Matthews JB, Sloan AJ, Smith AJ (2002) Age-related odontometric changes of human teeth. Oral Surg Oral Med Oral Pathol Oral Radiol Endodontol 93:474-482. https://doi. org/10.1067/moe.2002.120974

15. Conrads G, About I (2018) Pathophysiology of dental caries. Monogr Oral Sci 27:1-10. https://doi.org/10.1159/000487826

16. Philippas GG (1961) Influence of occlusal wear and age on formation of dentin and size of Ppulp chamber. J Dent Res 40:11861198. https://doi.org/10.1177/00220345610400061301

17. Stanley HR, White CL, McCray L (1966) The rate of tertiary (reparative) dentine formation in the human tooth. Oral Surg Oral Med Oral Pathol 21:180-189. https://doi.org/10.1016/00304220(66)90240-4

18. Philippas GG, Applebaum E (1968) Location of irregular secondary dentin formation. J Dent Res 47:769-778. https://doi.org/10. 1177/00220345680470051801

19. Ricucci D, Loghin S, Niu L-N, Tay FR (2018) Changes in the radicular pulp-dentine complex in healthy intact teeth and in response to deep caries or restorations: a histological and histobacteriological study. J Dent 73:76-90. https://doi.org/10. 1016/j.jdent.2018.04.007

20. Marroquin Penaloza TY, Karkhanis S, Kvaal SI, Vasudavan S, Castelblanco E, Kruger E, Tennant M (2017) Orthodontic treatment: real risk for dental age estimation in adults? J Forensic Sci 62:907-910. https://doi.org/10.1111/1556-4029.13371

21. Kazmi S, Mânica S, Revie G, Shepherd S, Hector M (2019) Age estimation using canine pulp volumes in adults: a CBCT image analysis. Int J Legal Med 133:1967-1976. https://doi.org/10.1007/ s00414-019-02147-5

22. Ge Z-P, Yang P, Li G, Zhang J-Z, Ma X-C (2016) Age estimation based on pulp cavity/chamber volume of 13 types of tooth from cone beam computed tomography images. Int J Legal Med 130: 1159-1167. https://doi.org/10.1007/s00414-016-1384-6

23. Zhang Z-Y, Yan C-X, Min Q-M, Li S-Q, Yang J-S, Guo Y-C, Jin W-F, Li L-J, Xing P-F, Li J (2019) Age estimation using pulp/ enamel volume ratio of impacted mandibular third molars measured on CBCT images in a northern Chinese population. Int J Legal Med 133:1925-1933. https://doi.org/10.1007/s00414-019-02112-2

24. Asif MK, Nambiar P, Mani SA, Ibrahim NB, Khan IM, Lokman NB (2019) Dental age estimation in Malaysian adults based on volumetric analysis of pulp/tooth ratio using CBCT data. Leg Med Tokyo Jpn 36:50-58. https://doi.org/10.1016/j.legalmed. 2018.10.005

25. Asif MK, Nambiar P, Mani SA, Ibrahim NB, Khan IM, Sukumaran P (2018) Dental age estimation employing CBCT scans enhanced with Mimics software: comparison of two different approaches using pulp/tooth volumetric analysis. J Forensic Leg Med 54:5361. https://doi.org/10.1016/j.jflm.2017.12.010

26. Gulsahi A, Kulah CK, Bakirarar B, Gulen O, Kamburoglu K (2018) Age estimation based on pulp/tooth volume ratio measured on cone-beam CT images. Dento Maxillo Facial Radiol 47: 20170239. https://doi.org/10.1259/dmfr.20170239

27. Signorelli L, Patcas R, Peltomäki T, Schätzle M (2016) Radiation dose of cone-beam computed tomography compared to conventional radiographs in orthodontics. J Orofac Orthop Fortschr Kieferorthop Organ Off J Dtsch Ges Kieferorthop 77:9-15. https://doi.org/10.1007/s00056-015-0002-4

28. Demirturk Kocasarac H, Geha H, Gaalaas LR, Nixdorf DR (2018) MRI for dental applications. Dent Clin North Am 62:467-480. https://doi.org/10.1016/j.cden.2018.03.006

29. Idiyatullin D, Corum C, Moeller S, Prasad HS, Garwood M, Nixdorf DR (2011) Dental magnetic resonance imaging: making the invisible visible. J Endod 37:745-752. https://doi.org/10.1016/ j.joen.2011.02.022

30. Geibel MA, Schreiber ES, Bracher AK, Hell E, Ulrici J, Sailer LK, Ozpeynirci Y, Rasche V (2015) Assessment of apical periodontitis by MRI: a feasibility study. ROFO Fortschr Geb Rontgenstr Nuklearmed 187:269-275. https://doi.org/10.1055/s-00341385808

31. Bjørk MB, Kvaal SI (2018) CT and MR imaging used in age estimation: a systematic review. J Forensic Odontostomatol 36:14-25

32. Guo Y, Olze A, Ottow C, Schmidt S, Schulz R, Heindel W, Pfeiffer H, Vieth V, Schmeling A (2015) Dental age estimation in living individuals using 3.0 T MRI of lower third molars. Int J Legal Med 129:1265-1270. https://doi.org/10.1007/s00414-015-1238-7

33. De Tobel J, Bauwens J, Parmentier GIL, Franco A, Pauwels NS, Verstraete KL, Thevissen PW (2020) Magnetic resonance imaging for forensic age estimation in living children and young adults: a systematic review. Pediatr Radiol. https://doi.org/10.1007/s00247020-04709-x

34. Hövener J-B, Zwick S, Leupold J, Eisenbei $\beta$ A-K, Scheifele C, Schellenberger F, Hennig J, Elverfeldt DV, Ludwig U (2012) Dental MRI: imaging of soft and solid components without ionizing radiation. J Magn Reson Imaging JMRI 36:841-846. https://doi. org/10.1002/jmri.23712

35. Weiger M, Pruessmann KP, Bracher A-K, Köhler S, Lehmann V, Wolfram U, Hennel F, Rasche V (2012) High-resolution ZTE imaging of human teeth. NMR Biomed 25:1144-1151. https://doi. org/10.1002/nbm. 2783 
36. Bracher A-K, Hofmann C, Bornstedt A, Hell E, Janke F, Ulrici J, Haller B, Geibel M-A, Rasche V (2013) Ultrashort echo time (UTE) MRI for the assessment of caries lesions. Dento Maxillofac Facial Radiol 42:20120321. https://doi.org/10.1259/ dmfr.20120321

37. Grosse U, Syha R, Papanikolaou D, Martirosian P, Grözinger G, Schabel C, Schick F, Springer F (2013) Magnetic resonance imaging of solid dental restoration materials using 3D UTE sequences: visualization and relaxometry of various compounds. Magma N Y N 26:555-564. https://doi.org/10.1007/s10334-013-0373-8

38. Stumpf K, Kaye E, Paul J, Wundrak S, Pauly JM, Rasche V (2020) Two-dimensional UTE overview imaging for dental application. Magn Reson Med. 84:2616-2624. https://doi.org/10.1002/mrm. 28312

39. Larson PEZ, Han M, Krug R, Jakary A, Nelson SJ, Vigneron DB, Henry RG, McKinnon G, Kelley DAC (2016) Ultrashort echo time and zero echo time MRI at 7 T. Magma N Y N 29:359-370. https:// doi.org/10.1007/s10334-015-0509-0

40. De Cocker LJ, Lindenholz A, Zwanenburg JJ, van der Kolk AG, Zwartbol M, Luijten PR, Hendrikse J (2018) Clinical vascular imaging in the brain at 7 T. NeuroImage 168:452-458. https://doi.org/ 10.1016/j.neuroimage.2016.11.044
41. Winkler SA, Schmitt F, Landes H, de Bever J, Wade T, Alejski A, Rutt BK (2018) Gradient and shim technologies for ultra high field MRI. NeuroImage 168:59-70. https://doi.org/10.1016/j. neuroimage.2016.11.033

42. Brüllmann D, Schulze RKW (2015) Spatial resolution in CBCT machines for dental/maxillofacial applications-what do we know today? Dento Maxillofac Facial Radiol 44:20140204. https://doi. org/10.1259/dmfr.20140204

43. Spin-Neto R, Gotfredsen E, Wenzel A (2013) Impact of voxel size variation on CBCT-based diagnostic outcome in dentistry: a systematic review. J Digit Imaging 26:813-820. https://doi.org/10. 1007/s10278-012-9562-7

44. Marroquin Penaloza TY, Karkhanis S, Kvaal SI, Vasudavan S, Castelblanco E, Kruger E, Tennant M (2016) Reliability and repeatability of pulp volume reconstruction through three different volume calculations. J Forensic Odontostomatol 34:35-46

Publisher's note Springer Nature remains neutral with regard to jurisdictional claims in published maps and institutional affiliations. 